\title{
The nuclear matrix protein CIZ1 facilitates localization of Xist RNA to the inactive $\mathrm{X}$-chromosome territory
}

\author{
Rebeca Ridings-Figueroa, ${ }^{1,7}$ Emma R. Stewart, ${ }^{1}$ Tatyana B. Nesterova, ${ }^{2}$ Heather Coker, ${ }^{2}$ \\ Greta Pintacuda, ${ }^{2}$ Jonathan Godwin, ${ }^{2}$ Rose Wilson, ${ }^{1,8}$ Aidan Haslam, ${ }^{1}$ Fred Lilley, ${ }^{1}$ Renate Ruigrok, ${ }^{3}$ \\ Sumia A. Bageghni, ${ }^{3}$ Ghadeer Albadrani, ${ }^{3,4}$ William Mansfield, ${ }^{5}$ Jo-An Roulson, ${ }^{6}$ Neil Brockdorff, ${ }^{2}$ \\ Justin F.X. Ainscough, ${ }^{1,3}$ and Dawn Coverley ${ }^{1}$ \\ ${ }^{1}$ Department of Biology, University of York, York YO10 5DD, United Kingdom; ${ }^{2}$ Department of Biochemistry, University of \\ Oxford, Oxford OX13QU, United Kingdom; ${ }^{3}$ Leeds Institute of Cardiovascular and Metabolic Medicine (LICAMM), University of \\ Leeds, Leeds LS2 9JT, United Kingdom; ${ }^{4}$ Princess Nourah Bint Abdulrahman University (PNU), Riyadh, Kingdom of Saudi Arabia; \\ ${ }^{5}$ Stem Cell Institute, University of Cambridge, Cambridge CB2 1QR, United Kingdom; ${ }^{6}$ Leeds Institute of Molecular Medicine \\ (LIMM), University of Leeds, Leeds LS9 7TF, United Kingdom
}

The nuclear matrix protein Cip1-interacting zinc finger protein 1 (CIZ1) promotes DNA replication in association with cyclins and has been linked to adult and pediatric cancers. Here we show that CIZ1 is highly enriched on the inactive $\mathrm{X}$ chromosome $(\mathrm{Xi})$ in mouse and human female cells and is retained by interaction with the RNA-dependent nuclear matrix. CIZ1 is recruited to Xi in response to expression of $X$ inactive-specific transcript (Xist) RNA during the earliest stages of $X$ inactivation in embryonic stem cells and is dependent on the $C$-terminal nuclear matrix anchor domain of CIZ1 and the E repeats of Xist. CIZ1-null mice, although viable, display fully penetrant female-specific lymphoproliferative disorder. Interestingly, in mouse embryonic fibroblast cells derived from CIZ1null embryos, Xist RNA localization is disrupted, being highly dispersed through the nucleoplasm rather than focal. Focal localization is reinstated following re-expression of CIZ1. Focal localization of Xist RNA is also disrupted in activated B and T cells isolated from CIZ1-null animals, suggesting a possible explanation for female-specific lymphoproliferative disorder. Together, these findings suggest that CIZ1 has an essential role in anchoring Xist to the nuclear matrix in specific somatic lineages.

[Keywords: CIZ1; Xist; X-chromosome inactivation; nuclear matrix; lymphoproliferative disorder]

Supplemental material is available for this article.

Received January 5, 2017; revised version accepted April 20, 2017.

In mammals, dosage compensation for X-linked transcripts is achieved by the developmentally regulated inactivation of one of the two X chromosomes in female cells. $\mathrm{X}$-chromosome inactivation $(\mathrm{XCI})$ is initiated by $\mathrm{X}$ inactive-specific transcript (Xist), a noncoding RNA $\sim 17 \mathrm{~kb}$ in length (Brockdorff et al. 1992; Brown et al. 1992; Lee et al. 1996; Penny et al. 1996). Xist RNA is expressed from the inactive $\mathrm{X}$ chromosome (Xi) elect and accumulates in cis to form a domain over the entire chromosome, serving as a trigger for a cascade of chromatin modifications that results in the progressive transition toward a stable, heritable, repressed state (for review, see Heard and Disteche 2006).

Analysis of Xist transgenes has revealed that Xist-mediated chromosome silencing and Xist RNA localization are

Present addresses: ${ }^{7}$ Department of Genetics, University of Cambridge, Cambridge CB2 3EH, UK; ${ }^{8}$ Wellcome Trust Centre for Human Genetics, Oxford OX3 7BN, UK.

Corresponding author: dawn.coverley@york.ac.uk

Article published online ahead of print. Article and publication date are online at http://www.genesdev.org/cgi/doi/10.1101/gad.295907.117. Freely available online through the Genes \& Development Open Access option. conferred by distinct elements (Wutz et al. 2002). Silencing activity maps in large part to the A repeat, a short tandemly repeated region located at the $5^{\prime}$ end of Xist. In contrast, localization maps to several redundantly acting elements, including the tandem repeat regions $\mathrm{C}, \mathrm{E}$, and F (Wutz et al. 2002; Jeon and Lee 2011; Makhlouf et al. 2014; Yamada et al. 2015).

Xist spreading occurs through a sequence of events dictated by the architecture of the X chromosome. Xist RNA searches for binding sites in three dimensions, leading to modification of chromosome structure, before spreading to newly accessible locations (Engreitz et al. 2013; Simon et al. 2013). While the nature of Xist RNA-binding sites is poorly defined, it is known that Xist RNA localizes to the perichromatin compartment that corresponds to the nuclear matrix (NM) (Clemson et al. 1996; Smeets et al. 2014). Accordingly, the NM proteins scaffold attachment

(C) 2017 Ridings-Figueroa et al. This article, published in Genes \& Development, is available under a Creative Commons License (Attribution-NonCommercial 4.0 International), as described at http://creativecommons. org/licenses/by-nc/4.0/. 
factor A (SAF-A; hnRNPU) and hnRNP UL1 are involved in anchoring Xist RNA within Xi (Helbig and Fackelmayer 2003; Hasegawa et al. 2010; Sakaguchi et al. 2016). Additionally, NM protein 1 (NMP1; YY1) (Guo et al. 1995) has been implicated in tethering Xist RNA to chromatin (Jeon and Lee 2011; Makhlouf et al. 2014). In naïve B and T cells, Xist RNA is dispersed in the nucleoplasm but is recruited to $\mathrm{Xi}$ upon lymphocyte activation in a process that involves YY1 and SAF-A (Wang et al. 2016).

Recent proteomic and genetic screens have identified several novel Xist-interacting factors, some of which now have confirmed roles in Xist-mediated silencing (Chu et al. 2015; McHugh et al. 2015; Moindrot et al. 2015; Monfort et al. 2015). With the exception of SAF-A identified previously (Hasegawa et al. 2010), none of the factors investigated in detail was found to affect Xist localization (Chu et al. 2015; McHugh et al. 2015).

Random XCI of the paternal or maternal chromosome occurs around embryonic day 5.5 (E5.5) and is propagated through subsequent cell divisions. This can be recapitulated in XX mouse embryonic stem cells (mESCs), allowing fine-tuned analysis of the timing and the earliest events in the initiation process. Examples include deposition of histone 3 Lys27 trimethylation (H3K27me3) and hypoacetylation of $\mathrm{H} 4$, which occur rapidly at the onset of Xist RNA expression, and DNA methylation of promoters of X-linked genes and association of the variant histone macroH2A, which occur at later stages of the XCI process (Pollex and Heard 2012). Xist-dependent silencing occurs within a developmental window of opportunity corresponding to early stages of differentiation in the XX ESC model (Wutz and Jaenisch 2000). Beyond this time, $\mathrm{XCI}$ enters a maintenance phase in which Xist is largely dispensable (Brown and Willard 1994; Csankovszki et al. 1999) despite continued expression.

Here we define a novel Xist localization factor, the NM protein Cipl-interacting zinc finger protein 1 (CIZ1). CIZ1 was characterized previously as a factor with roles in initiation of DNA replication (Coverley et al. 2005), interacting directly with CDK2, p21/CIP1 (Mitsui et al. 1999), and cyclins (Copeland et al. 2010) and supporting cyclin recruitment to the NM (Copeland et al. 2015). The NM anchor domain in the C-terminal third of CIZ1 (Ainscough et al. 2007) mediates immobilization of CIZ1 and its interaction partners but retains the ability to become incorporated into the NM in the absence of cyclin cargo. CIZ1 has also been linked with post-replicative functions in male germ cell differentiation (Greaves et al. 2012). CIZ1 transcripts are alternatively spliced to yield at least 22 variants (Rahman et al. 2010), most of which are not characterized. Aberrant alternative splicing underlies its links with a range of pathologies, including pediatric tumors and common adult-onset cancers of the breast (den Hollander et al. 2006) and lung (Higgins et al. 2012) as well as neurological abnormalities (Xiao et al. 2016). Here we describe Xist-dependent recruitment of CIZ1 to $\mathrm{Xi}$ and a requirement for CIZ1 to maintain Xist RNA localization at Xi in fibroblasts and splenocytes.

\section{Results}

\section{CIZ1 accumulates at Xi in female cells}

Immunolocalization of endogenous CIZ1 via epitopes in its N-terminal DNA replication domain (Coverley et al. 2005; Copeland et al. 2010) or C-terminal NM anchor domain (Fig. 1A; Ainscough et al. 2007) reveal one or two high-intensity domains within the nucleus of female human or mouse cultured fibroblasts plus smaller nucleus-wide foci in both male and female cells (Fig. 1B; Supplemental Fig. S1A). In immortalized or primary embryonic fibroblasts (PEFs), CIZ1 domains are discrete, while, in cancer-derived cell lines, they are more irregular (shown for MCF7 breast cancer cells in Supplemental Fig. S1A). We hypothesized that the high-intensity domains present only in female cells correspond to Xi. Consistent with this, immunostaining of $\mathrm{H} 3 \mathrm{~K} 27 \mathrm{me} 3$, a marker for $\mathrm{Xi}$, colocalizes with CIZ1 in PEFs (Fig. 1B) and a range of other female cell types (Supplemental Fig. S1A). CIZ1 did not colocalize with the active chromatin mark $\mathrm{H} 3 \mathrm{~K} 4 \mathrm{me} 3$ or constitutive heterochromatin mark H3K9me3 (Supplemental Fig. S1B). Identification of the CIZ1 domains observed in female PEFs as the silenced $X$ chromosome was confirmed by immuno-FISH for CIZ1 and Xist RNA (Fig. 1C), which revealed localization within the same chromosome territory.

To determine at which stage of the XCI process CIZ1 is recruited, we analyzed CIZ1 localization in PGK12.1 XX mESCs at time points following the initiation of differentiation. CIZ1 localization to Xi was observed from day 1 and persisted throughout the time course (Fig. 1D, Supplemental Fig. S1C). This closely correlates with the dynamics of Xist RNA expression reported previously (Sheardown et al. 1997). As in PEFs, CIZ1 domains colocalized with H3K27me3, identifying their location as Xi. $\mathrm{CIZ1}$ is lost from $\mathrm{Xi}$ in late metaphase in both ESCs (Fig. 1E) and PEFs (Supplemental Fig. S1D), indicating a cycle of recruitment and loss that is similar to Xist RNA (Duthie et al. 1999). The smaller nucleus-wide foci remain qualitatively similar throughout ESC differentiation but are excluded from chromosomes in late metaphase (Supplemental Fig. S1D; Greaves et al. 2012).

Superresolution three-dimensional structured illumination microscopy (SR 3D-SIM) of endogenous CIZ1 together with endogenous Xist RNA in diploid female somatic C127I cells confirmed their adjacent localization, similar to that for SAF-A (Fig. 2A; Supplemental Fig. S2B; Smeets et al. 2014).

\section{NM association of CIZ1 at Xi}

The NM is a biochemically defined fraction that resists extraction from the nucleus and is thought to anchor and spatially organize nuclear processes, including DNA replication and repair, transcription, and pre-mRNA splicing (Wilson and Coverley 2013). Serial extraction (Wilson et al. 2016) to reveal the fraction of CIZ1 that remains in cells after solubilization with (1) low-level detergent under physiological salt concentrations, (2) $0.5 \mathrm{M}$ salt, or 

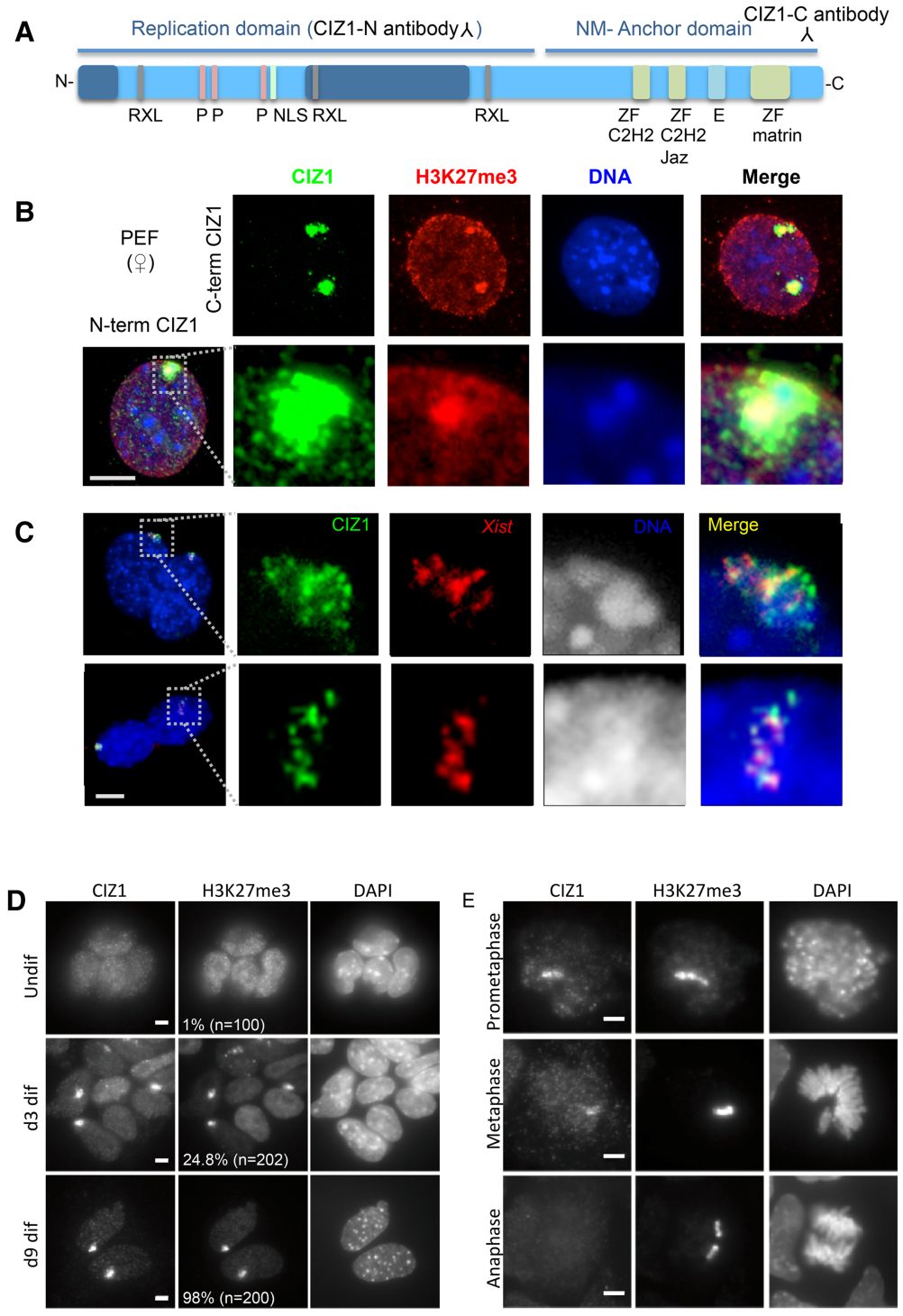

Figure 1. CIZ1 is enriched at Xi. (A) Schematic of CIZ1 indicating the replication domain /Copeland et al. 2015) with the nuclear localization signal (NLS, green), functional CDK phosphorylation sites (pink), and RXL cyclin-binding motifs (gray) and the NM anchor domain (Ainscough et al. 2007) with the locations of C2H2-type zinc fingers (green), the Matrin3-type RNA-binding zinc finger (Prosite PS50171), and the acidic domain (labeled E). The locations of epitopes recognized by $\mathrm{N}$-terminal and $\mathrm{C}$-terminal antibodies are indicated. $(B)$ Immunodetection of CIZ1 (green) in female PEFs from wild-type mice using $\mathrm{N}$-terminal and C-terminal antibodies. Colocalization of CIZ1 and histone $\mathrm{H} 3 \mathrm{~K} 27 \mathrm{me} 3$ (red) was observed as a discrete domain in all cells with H3K27me3 staining. $n>100$. DNA was stained with DAPI (blue). Additional cell lines are shown in Supplemental Figure S1; some have two domains, indicative of chromosomal duplication. (C) RNA-FISH for Xist (red) in female PEFs showing colocalization with CIZ1 protein (green) and the Barr body (gray). Bar, $5 \mu \mathrm{M}$. (D) CIZ1 recruitment to $\mathrm{Xi}$ in differentiating XX ESCs correlates with Xistmediated deposition of $\mathrm{H} 3 \mathrm{~K} 27 \mathrm{me} 3 . \mathrm{d} 3$ and $\mathrm{d} 9$ are days of differentiation after withdrawal of LIF. Additional time points are shown in Supplemental Figure S1C. (E) CIZ1 and H3K27me3 in differentiated XX ESCs during mitosis showing a reduction of CIZ1 in late metaphase and complete loss in anaphase but retention of H3K27me3. Bar, $5 \mu \mathrm{m}$.
(3) nuclease (DNase or RNase) (Fig. 2B) revealed distinct populations in female 3T3 cells (Fig. 2C) and PEFs (Supplemental Fig. S2C). While the small nucleus-wide foci remained under all conditions (part of the core protein $\mathrm{NM}$ ), the high-intensity domain at $\mathrm{Xi}$ was released by digestion with RNase but not DNase. This resistance to high salt and DNase defines CIZ1 at Xi as part of the NM, but release by RNase shows this to be the RNA fraction of the NM and is consistent with its close association with Xist RNA.

When 3T3 cells were treated with the protein-protein cross-linker DTSP prior to extraction (Fig. 2D), the CIZ1 domain at $\mathrm{Xi}$ was rendered resistant to digestion with RNase. This suggests that it is in close proximity to proteins in the core NM, possibly the resistant fraction of CIZ1. Thus, two qualitatively different populations of NM-anchored CIZ1 are present in the nucleus, but most of the $\mathrm{CIZ1}$ at $\mathrm{Xi}$ is anchored by association with RNA (Fig. 2E).

Similar analysis of the NM proteins SAF-A and YY1 in 3T3 cells showed that they are not enriched at $\mathrm{Xi}$, that a
NM-associated population can be revealed by removal of chromatin, and that both proteins are completely extracted by digestion of RNA (Supplemental Fig. S3). All three of these features are consistent with the published literature but distinguish SAF-A and YY1 from CIZ1.

\section{Recruitment to Xi requires the CIZ1 C-terminal NM anchor domain}

To ask whether recruitment of CIZ1 to $\mathrm{Xi}$ is mediated by the sequences that support attachment to the NM (Ainscough et al. 2007), the C-terminal anchor domain (GFPC275, which includes C2H2-type zinc fingers and Matrin3-type RNA-binding zinc finger domains) and the N-terminal DNA replication domain (GFP-N572, which includes CDK phosphorylation sites and cyclin-binding motifs) were transiently transfected separately into 3T3 cells, and the frequency of accumulation at the Xi territory was scored after one cell cycle. N572 completely failed to accumulate at $\mathrm{Xi}$, while $\mathrm{C} 275$ accumulated in large foci 


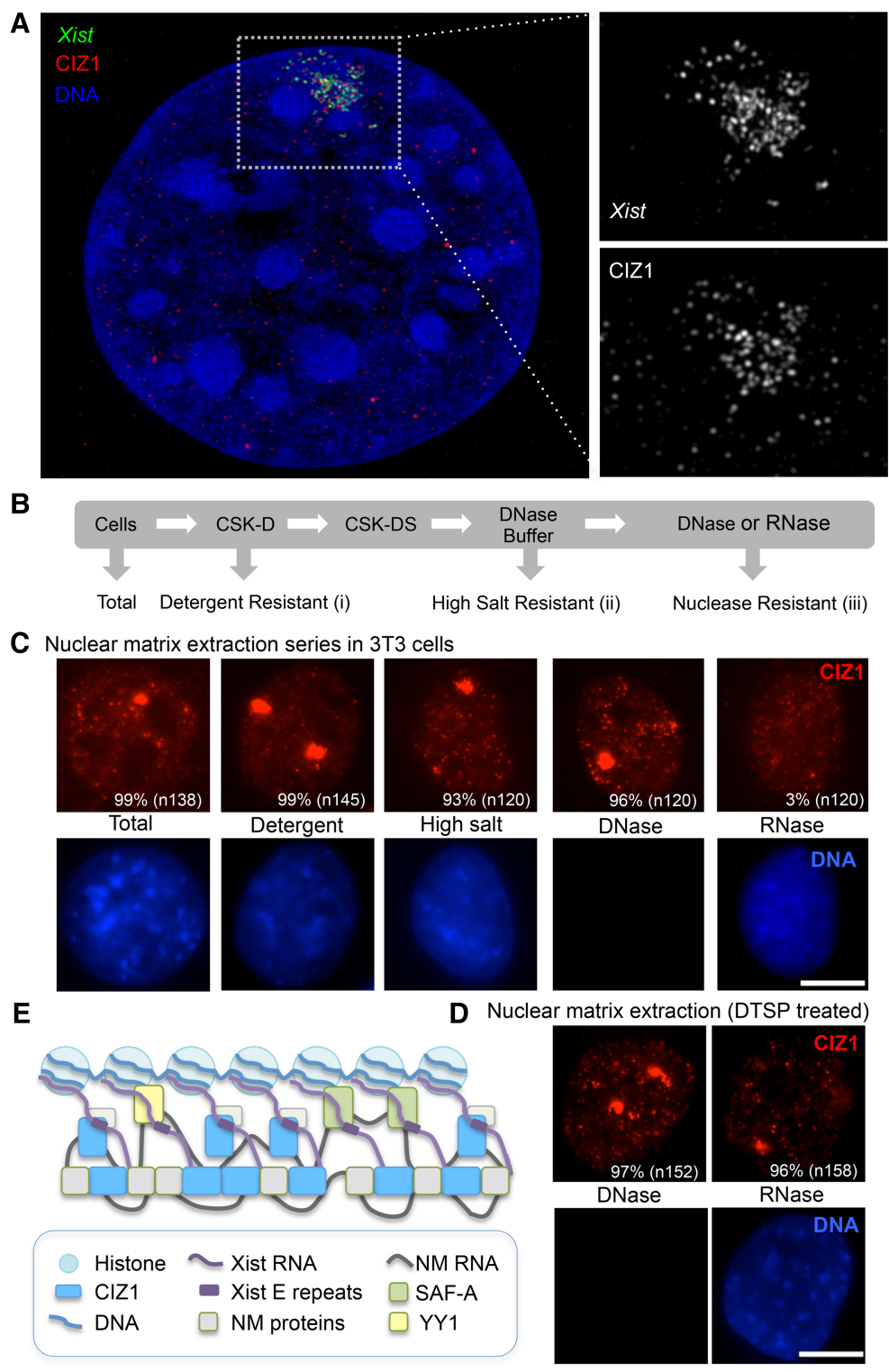

Figure 2. CIZ1 is part of the RNA-dependent NM at Xi. (A) Maximum intensity projection SR 3D-SIM image of a single C127I cell nucleus showing adjacent localization of Xist foci (green) with CIZ1 foci (red) at $X i$. Examples of individual $Z$ sections from several cells are shown in Supplemental Figure S2. $(B)$ Schematic showing the protocol for serial extraction with detergent, high salt, DNase, or RNase to reveal the protein-RNA NM fraction or the RNA-independent NM fraction (protein only). (C) Images show CIZ1 (red) after serial extraction of $3 \mathrm{~T} 3$ cells. The proportion of cells with discrete CIZ1-Xi domains is indicated $(n>100$ for each condition), some with two domains, indicating that a proportion of cells is tetraploids with two Xis. Similar results were obtained with PEFs (Supplemental Figure S2C). DNA (blue) shows the extent of nuclease treatment. Images were equally modified to allow direct comparison of fluorescence intensity across the different extraction conditions. Bar, $5 \mu \mathrm{m}$. $(D)$ As in $C$ but with prior protein-protein cross-linking with DTSP. $(E)$ Model showing two populations of CIZ1 in the NM (blue); RNA-dependent CIZ1 interacts with Xist, and RNA-independent CIZ1 is part of the core NM. SAFA (Hasegawa et al. 2010) is also shown interacting with Xist E repeats and is depicted with YY1 in the RNA-dependent NM.

that colocalized with endogenous CIZ1 at Xi (Fig. 3A). However, compared with GFP-full-length CIZ1, the frequency of C275-marked X chromosomes was significantly reduced despite their presence in the nucleus. Thus, while sequences encoded in N572 are not sufficient to specify recruitment to Xi on their own, they do increase the efficiency of targeting. Live-cell imaging of a stably transfected P4D7F4 XY mESC line, which carries an mCherry-tagged inducible Xist transgene (Moindrot et al. 2015), revealed colocalization between C275 and Xist RNA domains, whereas N572 showed no Xist colocalization (Fig. 3B). Together, these findings support a key role for the $\mathrm{C}$ terminus of $\mathrm{CIZ1}$ in binding at Xi.

\section{Recruitment of CIZ1 by Xist requires the Xist E repeat region}

In undifferentiated male MG-3E (XY) ESCs carrying an inducible Xist transgene, CIZ1 is recruited to the Xist domain and shows an adjacent localization to Xist similar to that in female ESCs (Supplemental Fig. S4A). To define elements in Xist RNA required for CIZ1 recruitment, we analyzed a series of inducible transgenic Xist deletion constructs in XY ESCs (Fig. 3C; Supplemental Fig. S5) and a deletion of Xist exon IV from the endogenous Xist locus in female mouse embryonic fibroblasts (MEFs) (Supplemental Fig. S4B; Caparros et al. 2002). The deletions encompassed key elements, including six short tandem repeat regions (A-F) (Brockdorff et al. 1992; Brown et al. 1992; Nesterova et al. 2001), which are conserved and, in some cases, have been shown to be functionally important. CIZ1 recruitment was found to be independent of the A repeat region, which is required for Xist-mediated silencing (Wutz et al. 2002), and the XN region (repeats B and F), which is involved in the recruitment of PRC2 to Xi (Fig. 3C; da Rocha et al. 2014). However, a truncated Xist construct, which corresponds to the first $3 \mathrm{~kb}$ of Xist, does not recruit CIZ1, implicating regions further 
A

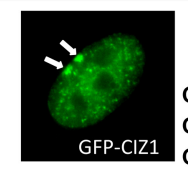

GFP-CIZ1 $81 \%$ GFP-N572 $0 \%$ GFP-C275 $14 \%$

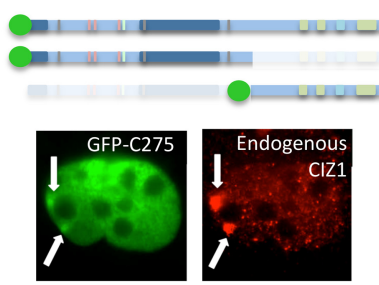

C

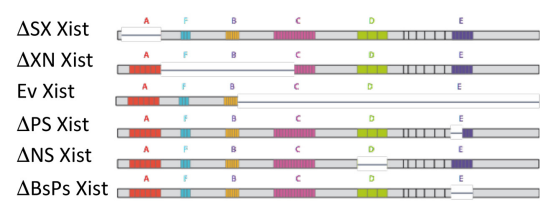

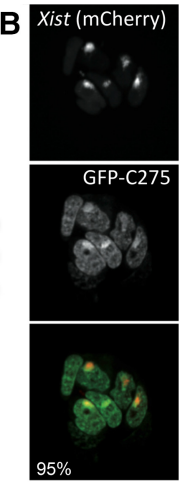

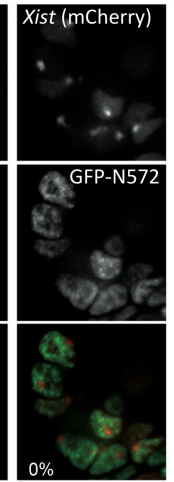

$\%$ of cells with $\mathrm{ClZ} 1$ enriched Xist domains

$$
90+/-7.1
$$

$98+/-3.5$

$0+/-0$

$72+/-5.2$

$99+/-1.4$

$0+/-0$
D

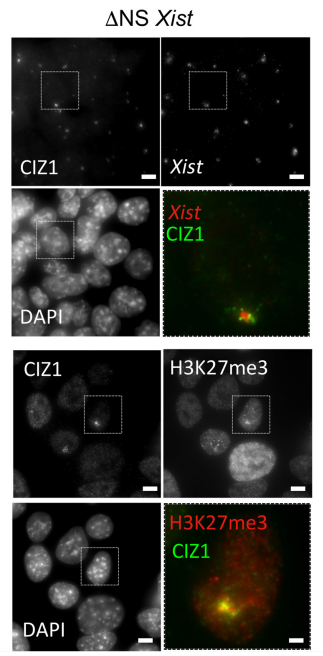

$\Delta$ BsPs Xist

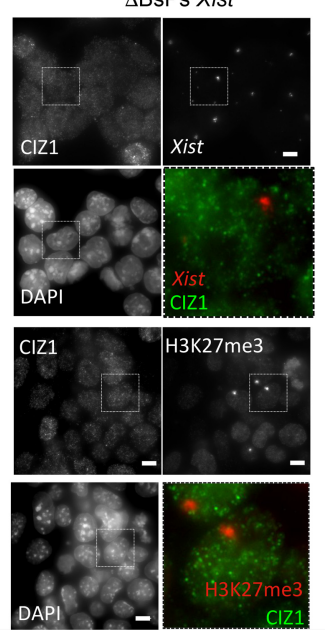

Figure 3. Delineation of the Xist and CIZ1 domains. (A) Recruitment of the indicated GFP-tagged CIZ1 constructs (Coverley et al. 2005) $24 \mathrm{~h}$ after transient transfection into cycling wildtype PEFs. The proportion of transfected cells with nuclear GFP, in which accumulation at Xi was observed $(n>100$ for each construct), is indicated with representative images. For GFP-C275, endogenous CIZ1 (red) is also shown, detected via epitopes in the N-terminal end. (B) Accumulation of GFP-C275 but not GFP-N572 at Xi in stably expressing ESC lines that also carry inducible Xist RNA tagged with Bgl stem-loops that bind a BglGmCherry fusion protein (Moindrot et al. 2015). Almost all (58 out of 61) Xist-mCherry-expressing cells were positive for GFP-C275, while none $(n=47)$ was positive for GFP-N572. (C) Schematic of inducible Xist constructs transfected into XY ESCs to study CIZ1 recruitment. The result of CIZ1 localization studies in the transgenic cell lines is summarized. $(D)$ Example images showing the lack of CIZ1 colocalization with H3K27me3 domains (bottom panels) or Xist (top panels) in a $\Delta \mathrm{BsPs}$ Xist construct missing the E repeat. The absence of the Xist $\mathrm{D}$ repeat $(\Delta \mathrm{NS})$ does not affect recruitment of CIZ1. Data for all transgenes are shown in Supplemental Figure S5.

$3^{\prime}$. Accordingly, deletion of the E repeats, encompassing a 1.5-kb span of Xist exon 7, entirely abolished CIZ1 recruitment by Xist RNA (Fig. 3D). Deletion of other $3^{\prime}$ regions, the $\mathrm{D}$ repeats, or the highly conserved Xist exon 4 had no effect (Fig. 3C,D; Supplemental Fig. S4B). These findings demonstrate a requirement for Xist $\mathrm{E}$ repeats for recruitment of CIZ1 and together raise the possibility that the $\mathrm{C}$ terminus of CIZ1 might functionally interact with Xist RNA via the E repeat region.

\section{Functional analysis of CIZ1 in XCI}

Loss-of-function mutations affecting factors critical for $\mathrm{XCI}$, including Xist RNA, result in female-specific lethality, usually during early or mid-stages of embryogenesis. To determine whether this is the case for CIZ1, targeted C57BL/6 ESCs generated using a gene trap strategy were used to produce heterozygous knockout mice (Supplemental Fig. S6A,B). Viable ciz1 $1^{-/-}$male and female F1 progeny were born at the expected ratio (Supplemental Table S1), showed no difference in growth rate, and had no overt developmental defects. Loss of ciz1 transcript was confirmed in embryos (E12) and fibroblasts from 3-wk postnatal tail tip dermal tissue (tail tip fibroblasts [TTFs]) (Supplemental Fig. S6C). Loss of protein expression was confirmed in TTFs, lymphocytes (Supplemental Fig. S6D,E), and differentiating male germ cells, which normally express high levels of CIZ1 (Supplemental Fig. S6F; Greaves et al. 2012). Thus, the gene trap insertion abrogates expression from the CIZ1 locus in vivo and in vitro, demonstrating that CIZ1 is not essential for embryogenesis, early postnatal development, or cell viability ex vivo.

The absence of an embryonic phenotype suggests that CIZ1 is not required for the establishment of a transcriptionally quiescent, inactivated $\mathrm{X}$ chromosome despite recruitment during Xist-dependent initiation of $\mathrm{X}$ inactivation (Fig. 1D). Consistent with this, the transcriptome of CIZ1-null-derived female PEFs did not reveal widespread reactivation of $\mathrm{Xi}$ compared with wild-type controls (Fig. 4A; Supplemental Data Set S1). As expected, the Ciz1 gene was silenced in null cells $\left(P=5.00 \times 10^{-05}\right.$; $q=0.005$ ) (Supplemental Data Set S2), but comparison of all transcripts that map to the $\mathrm{X}$ chromosome of the Mus musculus C57BL/6 primary assembly GRCm 38 (downloaded from http://www.ensembl.org on May 4, 2016) showed that most were not significantly altered and revealed little change in genes associated with the $\mathrm{X}$ inactivation center (XIC) (Fig. 4B). The lack of widespread reactivation is in line with similar analyses and the understanding that loss of Xist RNA or other factors does not significantly compromise the maintenance of XCI (Csankovszki et al. 1999).

However, deregulation at the single-gene level was significant $(P<0.05)$ for $62 \mathrm{X}$-linked transcription units dispersed across the $\mathrm{X}$. This is $3.6 \%$ of those that are expressed in PEFs and includes a similar number of upregulated and down-regulated genes and six where $q<$ 0.05 (Agtr2, Fhl1, Tmem164, Gpm6b, XLOC3750, and XLOC830) (Supplemental Data Set S2). Induction of the 
A
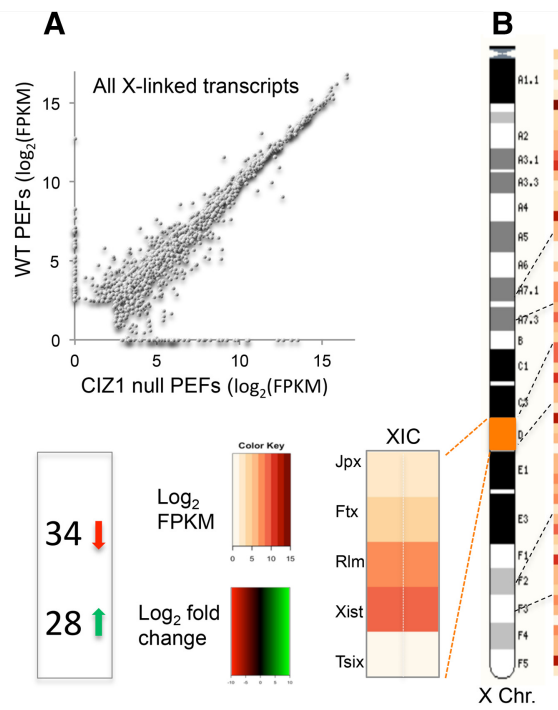

Significantly changed transcripts

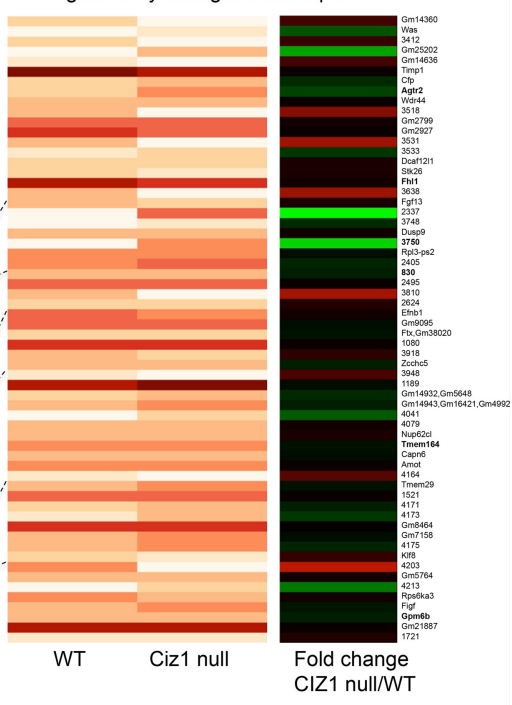

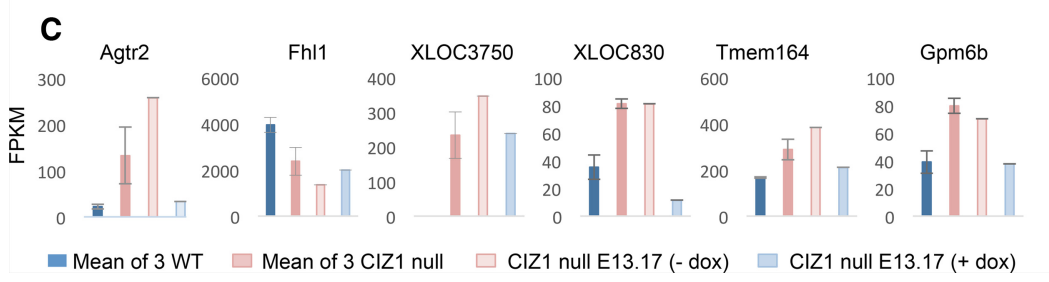

Figure 4. Expression of X-linked genes. $(A)$ Scatter plot showing mean expression in three wild-type and three CIZ1-null PEF lines $\left(\log _{2}\right.$ FPKM [fragments per kilobase per million mapped fragments]) for all expressed X-linked transcription units. FPKM $<0.99$ were rounded to 1 . The mean expression for all X-linked transcription units is in Supplemental Data Set S1. $(B)$ Heat map showing (white to brown) expression levels in $\log _{2}$ FPKM for 62 X-linked genes that are significantly changed in CIZ1-null PEFs. $P<0.05$. Genes are listed in order against a schematic of the $\mathrm{X}$ chromosome. Unannotated transcripts are indicated by XLOC gene ID number (Supplemental Data Set S1), and predicted genes are indicated by the prefix Gm. A list of significantly changed transcription units is in Supplemental Data Set S2, of which 35 are annotated, and 23 have known functions. (Right) Fold change showing the 34 down-regulated (red) and 28 up-regulated (green) transcription units distributed across the chromosome. (Left of the $\mathrm{X}$-chromosome schematic) Also shown are results for genes at the XIC. $(C)$ Expression of six X-linked transcription units where $q<0.05$, showing mean FPKM for three wild-type and three CIZ1-null cell lines as well as the effect of reinduction of CIZ1 in null-derived transgenic primary PEF line e13.17. full-length GFP-CIZ1 transgene in PEFs derived from CIZ1-null line e13.17 harboring an inducible CIZ1 transgene and doxycycline-regulatable transactivator (see the Supplemental Material) rebalanced the expression of all six genes, modulating four of them back to wild-type levels (Fig. 4C). Thus, expression of full-length CIZ1 compensates for genetic ablation and presumptive loss of the full repertoire of Ciz1 variant transcripts in the regulation of these genes.

\section{Lymphoproliferative disorder in adult female mice}

Although we observed no overt defects in embryogenesis or early postnatal development (Fig. 5), progressive infirmity was observed in female CIZ1-null mice from 9 mo onward. Eight females and an equivalent number of males were therefore evaluated for abnormalities between 9 and 19 mo. This revealed lymphoproliferative disorder in all eight females and none of the males. Detailed histological assessment was undertaken for six of the females and compared with six wild-type females. A summary assessment of abnormalities in the spleens, livers, lungs, and lymph nodes for individual CIZ1-null and wild-type females is in Supplemental Table S2, and pathology notes describing histological assessments are in Supplemental Tables S3 and S4. Notably, primary and secondary lymphoid tissues (spleen, lymph node, lung, and liver) were enlarged in all $\mathrm{Ciz}^{-1-}$ adult females (Fig. 5C). Secondary lymphoid tissues are sites where $\mathrm{B}$ and $\mathrm{T}$ lymphocytes are directed in search of antigen, leading to the regulated turnover or amplification of subsets of cells within germinal centers. This process is deregulated most notably in the spleen (Fig. 5C,D), which displayed a fivefold enlargement in $\mathrm{Ciz}^{-1-}(181-3679 \mathrm{mg})$ compared with $\mathrm{Ciz1}^{+/+}(88-167$ $\mathrm{mg}$ ) mice. Histologically, lymph node and spleen architectures were abnormal, with effacement of normal follicles and significant infiltration of abnormal B (CD20 +ve) and reactive $\mathrm{T}(\mathrm{CD} 3+\mathrm{ve})$ lymphocytes in all affected tissues (Fig. 5D,E). At the cellular level, the disorder resembled non-Hodgkin follicular-type lymphoma, with three showing evidence of high-grade transformation consistent with diffuse large B-cell lymphoma (Ward 2006). These data point to compromised XCI in lymphoid lineages and suggest that CIZ1 normally protects against tumor formation.

\section{CIZ1 is required for Xist RNA localization in fibroblasts and splenocytes}

While the viability of CIZ1-null embryos suggests that CIZ1 is not critical for the establishment of XCI, femalespecific lymphoid hyperproliferation nevertheless implies an important lineage-restricted function. To further investigate this, we performed RNA-FISH to analyze Xist domains in PEFs and splenocytes derived from CIZ1-null mice. In independently derived CIZ1-null fibroblast cell lines, we observed a strikingly dispersed Xist signal that occupies $40 \%$ of the nuclear area compared with $<5 \%$ in wild-type cells as well as loss of H3K27me3 (Fig. 6A). Dispersal cannot be attributed to increased Xist levels, as none of the three CIZ1-null PEFs showed any change in Xist transcript (Supplemental data set S1). X-chromosome 
A

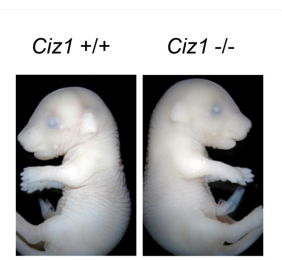

Day 15 embryo
B

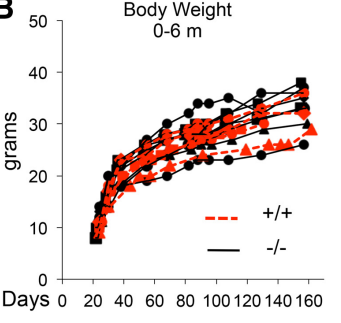
(a)
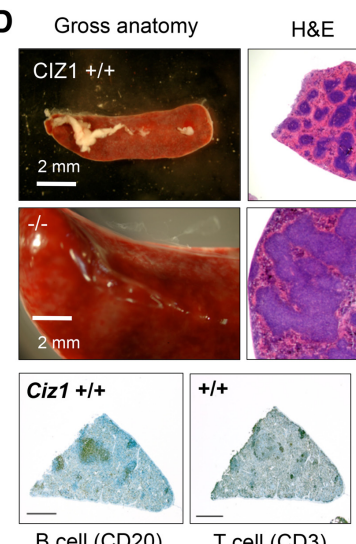

$B$ cell (CD20)
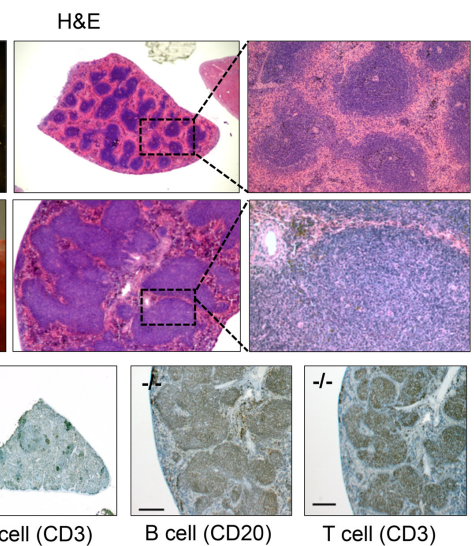
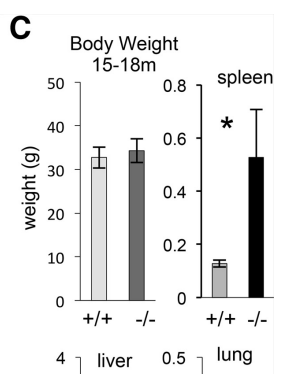

4 liver 0.5
E

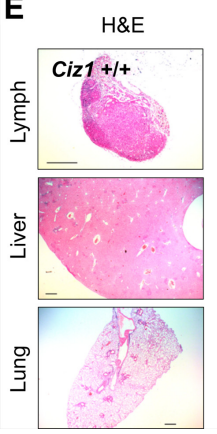

H\&E

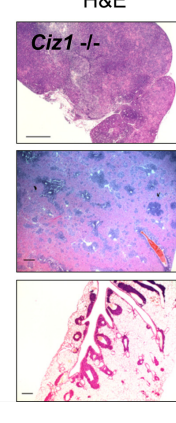

$B$ cell $(C D 20)$
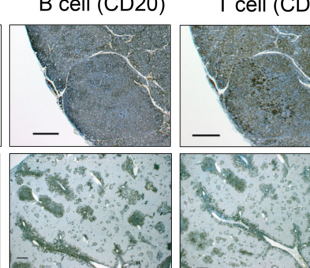
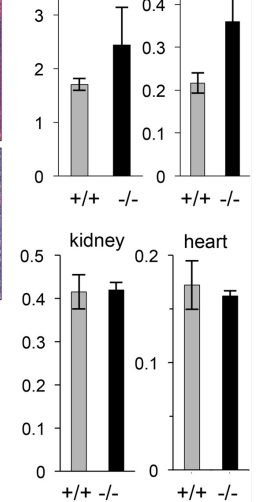

heart $+/+-1-\quad+/+-1-$ tion of CD20 and CD3 (B-cell-specific and T-cell-specific, respectively) suggests B-cell lymphoma with T-cell infiltration. Positive cells are stained dark gray and show overlapping distribution. Bar, $200 \mu \mathrm{m}$. (E) Representative H\&E staining of $\mathrm{Ciz}^{+/+}$and $\mathrm{Ciz} 1^{-/-}$female lymph nodes, livers, and lungs. Enlargement of secondary lymphoid tissues in $\mathrm{Ciz}^{-1-}$ females correlates with excess proliferation of lymphoid cells, as in $D$. (Right) Examples of gross tissue anatomy in $\mathrm{Ciz}^{-/-} \mathrm{fe}-$ males showing areas of lymphoproliferative disorder as pale outgrowths. Bar, $200 \mu \mathrm{m}$.

paints showed no significant difference between wild-type and CIZ1-null PEFs (Fig. 6B), suggesting that there is a deficit in Xist RNA localization rather than Xi organization.

Further substantiating the conclusion that CIZ1 plays a role in Xist RNA localization, induction of the full-length GFP-CIZ1 transgene (Fig. 6C-E) fully reinstated the localization of Xist RNA over Xi domains (Fig. 6F,G). Prior to induction of CIZ1, Xist was dispersed in $>80 \%$ of CIZ1null e13.17 PEFs but became relocalized to discrete domains that overlap with GFP-CIZ1 domains within $20 \mathrm{~h}$ (Fig. 6H). Together, these observations demonstrate that CIZ1 plays a key role in Xist RNA localization in PEFs.

In light of the female-specific lymphoproliferative disorder observed in CIZ1-null animals, we went on to investigate the role of CIZ1 in X inactivation in hematopoetic lineages. We evaluated the impact of CIZ1 deletion in splenocytes from 6-wk-old females after stimulation of mixed populations of naïve $\mathrm{B} / \mathrm{T}$ cells with either the $\mathrm{B}$ cell activator lipopolysaccharide (LPS) or T-cell activator aCD3 antibody ( $a \mathrm{CD} 3$ ). Consistent with a previous report (Wang et al. 2016), activation of both cell types from wildtype mice induced dramatic focal localization of Xist to Xi within $24 \mathrm{~h}$, and this was mirrored by accumulation of CIZ1 (Fig. 7). However, activated B and T lymphocytes from CIZ1-null mice failed to efficiently localize Xist RNA to the Xi territory (Fig. 7B). This finding identifies a transition point in the affected lineages that is compromised in CIZ1-null animals. To ask whether aberrant Xist localization leads to relaxed control over X-linked genes, we compared the transcriptomes of wild-type spleens (containing mostly naïve cells) and CIZ1-null spleens (containing hyperproliferative cell populations likely expanded from rare activated precursors) from adult mice. Overall, from the $2209 \mathrm{X}$-linked genes that returned test data (Supplemental Fig. S7A; Supplemental data set S2), $16.4 \%$ were up-regulated and $8.7 \%$ were down-regulated by greater than twofold (Supplemental Fig. S7B). As expected, whole-genome gene set enrichment analysis returned highly significant overlap with immunological processes and cell division gene ontology terms (Supplemental Fig. S7C; Supplemental data set S3). Comparison of the X-linked genes with the gene list reported to be up-regulated in blood cells of Xist mutant mice (Yildirim et al. 2013) showed that many of the same genes are 
A
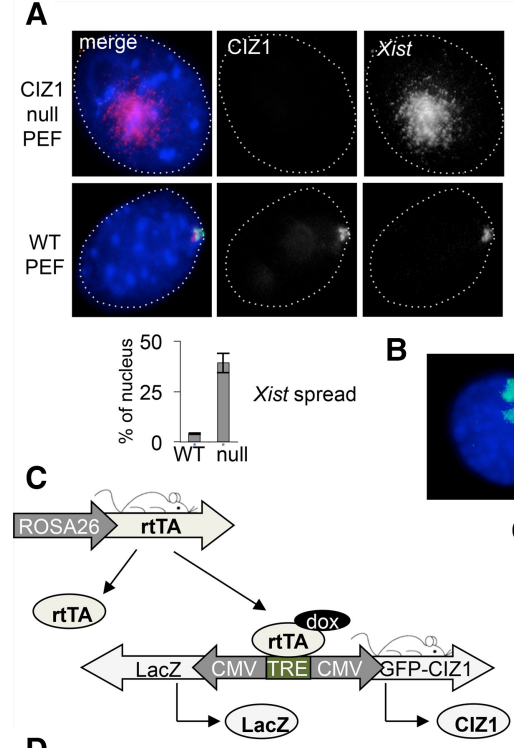

C

D
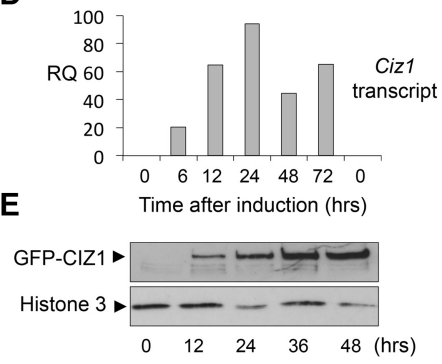

$\mathbf{F}$
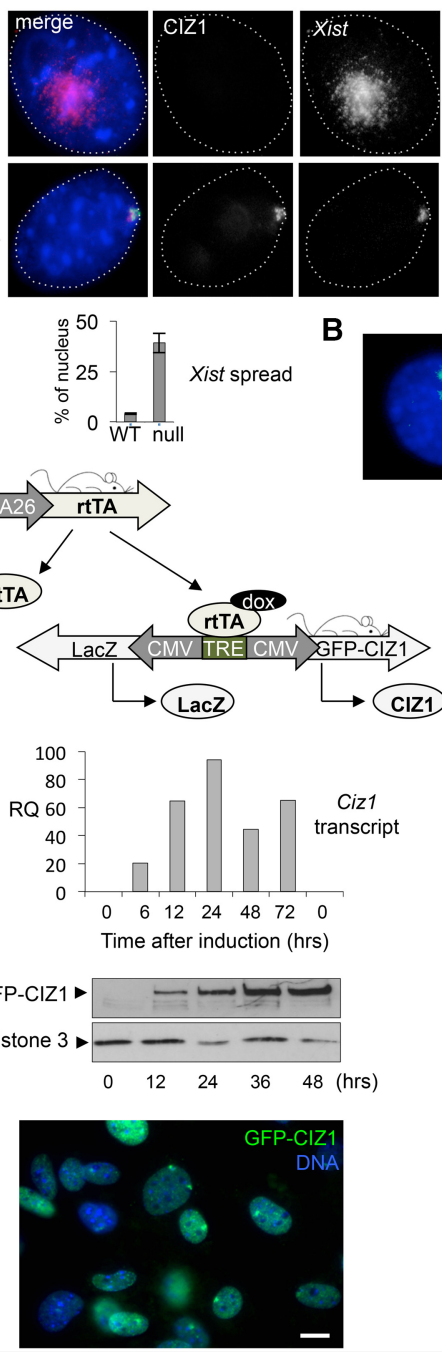
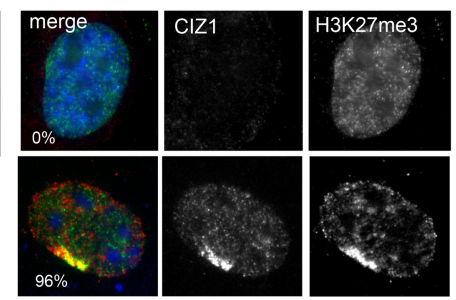

$\mathrm{X}$ chromosome paint

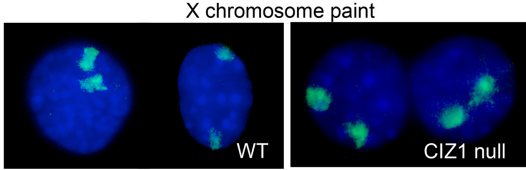

G Not induced 20 hours after dox induction
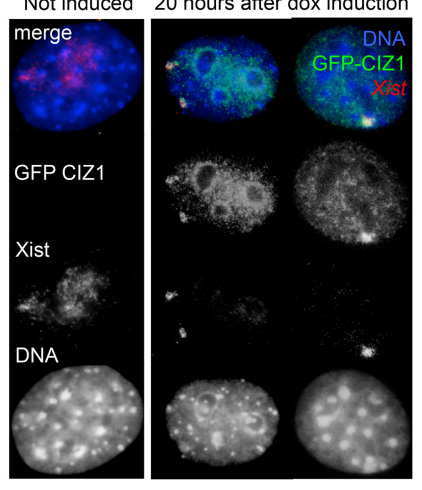

H

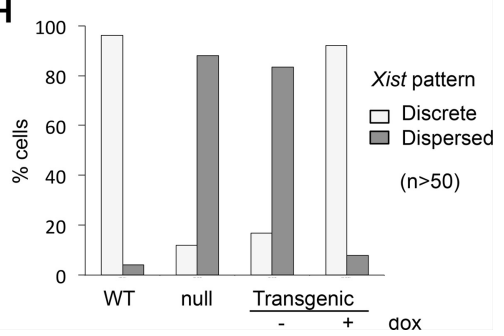

Figure 6. Loss and reinstatement of Xist localization at $\mathrm{Xi}$ is dependent on CIZ1. (A, left) Immuno-FISH showing CIZ1 and Xist RNA, which is delocalized in CIZ1-null $\left(\mathrm{ciz}^{-/-}\right)$PEFs. DNA was stained with DAPI (blue). (Below) Quantitation of the area of Xist FISH signal showing mean distribution over $~ 40 \%$ of the nucleus in CIZ1-null PEFs compared with $<5 \%$ in wild-type cells. (Right) CIZ1 and H3K27me3 in wild-type and CIZ1-null cells showing the proportion of cells with marked Xis. $n=100$. $(B) \mathrm{X}$-chromosome paint shows similar X-chromosome territories in CIZ1-null and wild-type PEFs. $(C)$ Double-transgenic female PEFs were derived from embryos harboring a tetracycline-responsive Ciz1 responder transgene and reverse transactivator transgene on the CIZ1-null background. $(D, E)$ Ciz1 transcript (primers Mm00503766_m1) (D) and protein (N-terminal antibody in whole-cell lysates) $(E)$ were detected after doxycycline induction. $(F)$ Representative field view of GFP-CIZ1 expressed from the transgene on a CIZ1-null background $24 \mathrm{~h}$ after induction with doxycycline. Note the presence of two domains in some cells, indicating two Xis in tetraploid cells. Bar, $10 \mu \mathrm{m}$. $(G)$ Expression of full-length CIZ1 in $c i z 1^{-/-}$PEFs leads to relocalization of Xist to the $\mathrm{Xi}$ territory. $(H)$ Quantitation of the proportion of cells with Xist FISH signal that is "dispersed" (defined as occupation of $>10 \%$ of the nuclear area). CIZ1 transgene induction reverts CIZ1-null cells to apparent normality for this criterium by $20 \mathrm{~h}$. affected (Supplemental Fig. S7D; Supplemental data set S4); however, a similar proportion of genes was affected genome-wide (Supplemental Fig. S7B). Together, the data demonstrate that CIZ1 plays a key role in stabilizing Xist association with $\mathrm{Xi}$ in lymphoid lineages but that its effects are not limited to the $\mathrm{X}$ chromosome.

\section{Discussion}

Here we demonstrate that the NM protein CIZ1 is strongly enriched over the Xi territory. Although CIZ1 was not previously linked to XCI, one of four recent screens identified CIZ1 among 81 candidate Xist interactors (Chu et al. 2015). Based on our findings, a relationship between CIZ1 and Xist is clear, although whether localization of CIZ1 to Xi domains is attributable to a direct interaction with Xist RNA or an interaction with other Xist or Xibound factors remains to be seen. Several observations support a functional interaction. First, loss of CIZ1 results in the dispersal of Xist in somatic cells. Second, CIZ1 enrichment occurs rapidly at the onset of Xist RNA expres- sion and is present in all observed cases in which Xist RNA domains are observed. Third, SR 3D-SIM analyses demonstrate that CIZ1 and Xist RNA lie in very close proximity and that CIZ1 is localized to the RNA-dependent NM compartment at Xi. Finally, the $\mathrm{C}$ terminus of CIZ1, which anchors it at Xi, encompasses known RNAbinding domains, notably the Matrin3-type zinc finger, suggesting a possible direct interaction. Interestingly, Matrin 3 has also been identified as a candidate Xist interactor (Chu et al. 2015; Moindrot et al. 2015). Further studies are nevertheless required to determine whether there is a direct interaction between CIZ1 and Xist RNA, specifically the E repeat region, and, at this stage, we cannot rule out that CIZ1 recognizes other Xist-interacting protein; for example, PTBP1 and PTBP2, recently shown to bind the E repeat region (Chen et al. 2016).

Several studies have pointed to a role for the NM in anchoring Xist RNA within the Xi territory, and a number of other proteins that interact with the NM or with DNA sequences that interact with the NM (S/MARs) have been implicated in XCI, including SAF-A, YY1, and SATB1. SAF-A and CIZ1 are similar in that their ability to support 
A $\mathrm{ClZ1}$ localisation in mouse splenocytes

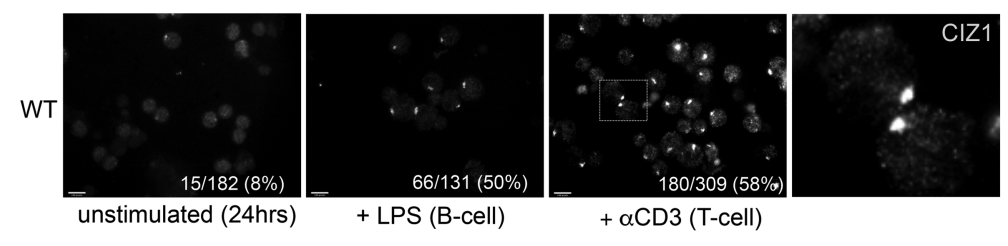

B Xist localisation in mouse splenocytes

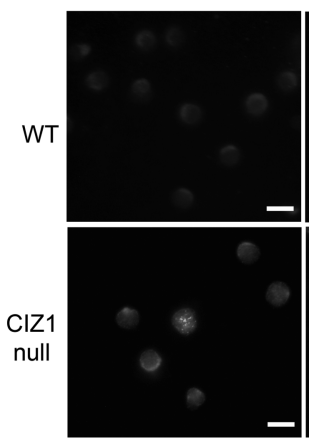

unstimulated (24 hrs)

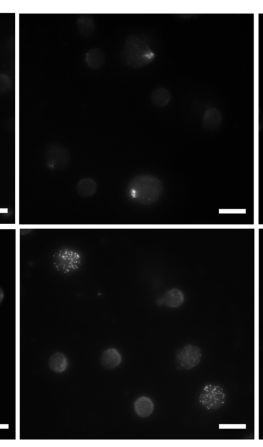

+ LPS (B-cell)

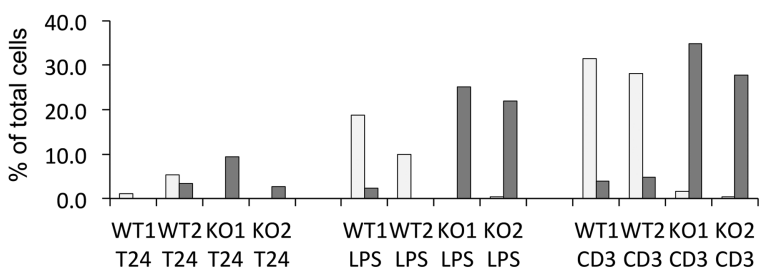

Xist-mediated gene silencing and recruitment of Xist to Xi, respectively, is dependent on Xist $\mathrm{E}$ repeats (Hasegawa et al. 2010), possibly identifying a common mechanism. Moreover, deletion of the E repeats was shown recently to result in dispersed localization of Xist RNA (Yamada et al. 2015). These findings were attributed to SAF-A; however, our results suggest that loss of interaction with CIZ1 might contribute to the observed phenotype. Notably, the sensitivity of both SAF-A and YY1 to digestion of the RNA component of the NM distinguish them from CIZ1, which is part of the core protein matrix throughout the nucleus, suggesting important differences in their roles.

Scaffolding the structural reorganization of Xi during $\mathrm{XCI}$ or the maintenance of the compacted structure are possible functions for the NM to which CIZ1 might contribute. Another possibility, suggested by the function of CIZ1 in DNA replication, is the regulatable recruitment of factors into or away from the Xi territory. During late G1 phase, CIZ1 supports the recruitment of cyclin A to the NM. Cyclin docking on CIZ1, but not CIZ1 recruitment to the NM, is switched off at S phase (Copeland et al. 2015). Thus, in the context of DNA replication, CIZ1 appears to be a cargo carrier or mediator that is sensitive to cell cycle stage, raising the possibility of a relationship with cell cycle regulators implicated in Xist retention (Hall et al. 2009).

Although our observations in PEFs and lymphocytes implicate CIZ1 in anchoring Xist to the NM, the fact
Figure 7. CIZ1 modulates Xist localization in splenocytes $(A)$ CIZ1 localization in wild-type splenocytes before and after activation with LPS or aCD3. Stimulation causes the accumulation of CIZ1 at $\mathrm{Xi}$ in both $\mathrm{B}$ and $\mathrm{T}$ lymphocytes within $24 \mathrm{~h}$. Bar, $10 \mu \mathrm{m}$. (B) Xist RNA localization in splenocytes before and after activation with LPS or $\mathrm{CCD} 3$. Similar to CIZ1, stimulation causes accumulation of Xist at $\mathrm{Xi}$ of wild-type B and T lymphocytes within $24 \mathrm{~h}$, whereas Xist RNA is not properly localized in CIZ1null cells. Bar, $10 \mu \mathrm{m} . n=200-300$ per group. that CIZ1-null females are viable implies that the same relationship might not apply during early embryogenesis. Based on this, we hypothesize that CIZ1 functions redundantly with other anchoring factors (for example, SAF-A) and that these are sufficient during embryogenesis but insufficient in PEFs or lymphocytes. A recent report suggested that SAF-A is not essential for Xist localization in all lineages and that other factors may compensate for its loss (Kolpa et al. 2016). However, this is in contrast to genetic depletion of SAF-A in MEFs, which showed a requirement for SAF-A (Sakaguchi et al. 2016). Thus, the relationship between CIZ1 and SAF-A is not known, and there may be more factors capable of anchoring Xist at $\mathrm{Xi}$.

Here we show that the compact localization of Xist upon the stimulation of lymphoid lineages (Wang et al. 2016) is dependent on CIZ1, describing a role for CIZ1 in a lineage-restricted transition that occurs throughout the lifetime of mice. An Xist-dependent silencing pathway was reported previously to be transiently activated during hematopoetic differentiation (Savarese et al. 2006), with pre-B and pre-T cells the most dependent. This aligns closely with our observation of B-cell and T-cell hyperplasia in CIZ1-null mice and is consistent with independent analysis that described a susceptibility to oncogene-induced transformation leading to leukemias in the absence of CIZ1, although no sex bias was reported in this study (Nishibe et al. 2013). 
We observed widespread deregulation of gene expression in the absence of CIZ1 in affected lineages, although this was not specific to the $\mathrm{X}$ chromosome. However, we cannot rule out that low-level reactivation of multiple $\mathrm{X}$-linked genes together, considered collectively, confers the female-specific lymphoproliferation phenotype. Thus, it remains an open question whether the disorder observed in CIZ1-null mice is a consequence of compromised XCI. Proliferative disorders of the hematopoetic system have been associated with deletion or suppression of factors linked with XCI (Leong et al. 2013; Yildirim et al. 2013), and abnormalities of XCI are reported frequently in cancers, including duplication of the active $\mathrm{X}$ (Xa) in breast and ovarian cancers and leukemias (Spatz et al. 2004; Lee and Bartolomei 2013). However, X chromosomes carry proportionally more immune-related genes than the rest of the genome (Bianchi et al. 2012), which means that a more general failure of the control of gene expression might manifest preferentially in females. Transcriptome analysis in PEFs identified candidate X-linked drivers of hematopoetic malignancies; Gpm6b overexpression is linked with B-cell lymphoma (Charfi et al. 2014), and Figf (VEGF-D) is implicated in the metastatic spread of tumors via lymph nodes (Bardelli et al. 2007; Pazgal et al. 2007). However, we interpret this with caution because changes elsewhere in the genome, initiated directly or indirectly as a consequence of the loss of CIZ1, are also likely to play a role.

In conclusion, we defined a novel component of the $X$ inactivation pathway: the NM protein CIZ1. Our results indicate that CIZ1 functionally interacts with Xist RNA via the $\mathrm{E}$ repeat region and, moreover, that CIZ1 facilitates in cis-localization of Xist RNA, functioning as an anchor to the NM in somatic cell lineages.

\section{Materials and methods}

Further details are available in the Supplemental Material.

\section{Animals and genotyping}

All animal work was carried out under a UK Home Office license. CIZ1-null mice were generated from C57BL/6 ES clone IST13830B6 (TIGM) harboring a neomycin resistance gene trap inserted downstream from exon 1. The absence of Ciz1/CIZ1 in homozygous progeny was confirmed by quantitative PCR, immunofluorescence, and immunoblot with CIZ1 N-terminal antibody. Inducible GFPCiz1-Tg mice, generated by pronuclear injection of a GFP full-length Ciz1 construct into CBA/C57BL6 fertilized eggs, were crossed with ROSA26-rtTA mice (Jackson Laboratories). All primers used for the characterization of Ciz1 targeting and the detection of transactivator and responder transgenes and sex are in the Supplemental Material.

\section{Cell lines}

All stable cell lines were grown following standard procedures. Mouse PEFs were derived from individual embryos at days 13-14 of gestation. Primary TTFs were generated from individual 3-wk-old mice. Genotype and sex were confirmed after explant culture using primers listed in the Supplemental Material. For in- ducible cells harboring ROSA26-rtTA and GFPCiz1-Tg transgenes, the addition of $5 \mu \mathrm{g} / \mathrm{mL}$ doxycycline to medium was used to induce detectable GFP-CIZ1 within $6 \mathrm{~h}$. ESCs were grown on feeders with the addition of LIF. Where applicable, Xist expression was induced with doxycycline at $1.5 \mu \mathrm{g} / \mathrm{mL}$. Male XY P4D7 ESCs, derived from the cross between Mus castaneous and 129+Ter/SvJcl and containing an rtTA cassette in the Gt(ROSA)26Sor locus (Moindrot et al. 2015) were used to generate stable autosomal integrants of Xist-inducible deletion variants.

\section{Splenocyte isolation and activation}

Spleens isolated from 6-wk-old wild-type and Ciz1-null females were pressed through 70-um nylon filters to dissociate naïve $B$ and T lymphocytes into medium (RPMI 1640; Invitrogen) supplemented with $10 \%$ fetal calf serum, $100 \mu / \mathrm{mL}$ penicillin, $10 \mu \mathrm{g} / \mathrm{mL}$ streptomycin, and $2 \mathrm{mM}$ L-glutamine. The cells were pelleted at $450 \mathrm{~g}$ for $5 \mathrm{~min}$ and then resuspended in red blood cell lysis solution (Sigma) for $3 \mathrm{~min}$ before being pelleted and resuspended in $2 \mathrm{~mL}$ of medium. The cell suspensions were counted with Trypan blue to determine viability and adjusted to $10 \times 10^{6}$ cells per milliliter. One-hundred microliters $\left(1 \times 10^{6}\right.$ cells $)$ was transferred into individual wells of a 96-well plate and supplemented with $100 \mu \mathrm{L}$ of $(1)$ medium for unactivated control, (2) $1 \mu \mathrm{g} / \mathrm{mL}$ LPS (Sigma) for B-cell activation, or (3) $1 \mu \mathrm{g} / \mathrm{mL}$ aCD3 (BioLegend) for T-cell activation. After 24-48 h, the cells were processed for RNA-FISH, immunofluorescence, and protein isolation.

Whole-genome RNA sequencing and bioinformatics

In brief, cell lines (detailed in the Supplemental Material) were grown to $80 \%$ density before RNA extraction and DNase I treatment. Libraries, optimized for 250- to 400-base-pair inserts, were prepared using NEBNext Ultra (Illumina), enriched for mRNA using NEBNext poly(A) mRNA magnetic isolation module, and sequenced to generate $\sim 5 \times 10^{7}$ reads per sample. STAR software was used to align reads to the C57BL/6 X chromosome. Transcriptome assembly and expression quantification were performed using Cufflinks and Cuffdiff. Of 85 differentially expressed X-linked transcription units $(P<0.05), 23$ were excluded due to differential expression between biological replicates. Heat maps and gene enrichment analysis were carried out as described in the Supplemental Material.

\section{Histology}

Following dissection, tissues were transferred immediately into histological grade formalin and processed after 24-48 h. Immunostaining for $\mathrm{CD}$ antigens was performed using rabbit antiCD3 for T cells (Abcam, ab16669) at 1:200 and goat anti-CD20 for B cells (Santa Cruz Biotechnology, sc7735) at 1:500.

\section{ESC differentiation}

Female PGK12.1 ESCs were grown in ES medium with LIF on gelatin without feeders. To induce differentiation, $1 \times 10^{6}$ cells were plated onto nongelatinized dishes without LIF. On day 3 , differentiating colonies were replated onto bacterial dishes to stimulate embryoid body formation. On day 7, embryoid bodies were transferred to nongelatinized dishes to reattach. Fibroblast outgrowths were passaged as required. 
NM extraction

Cells were serially extracted with (1) detergent to reveal soluble factors, (2) salt to reveal loosely bound chromatin-associated factors, (3) DNase I to reveal tightly attached chromatin-associated factors, and (4) RNase to reveal RNA-associated factors, as described (Wilson et al. 2016), with improvements detailed in the Supplemental Material. Coverslips were then fixed and processed for immunofluorescence.

\section{Immunofluorescence}

Cells were washed in PBS and either (1) fixed in 4\% PFA to reveal total protein or (2) treated with detergent prior to fixing to reveal chromatin- and NM-associated factors prior to incubation with primary antibody for $2 \mathrm{~h}$, and then secondary antibody for $1 \mathrm{~h}$. For the ESC differentiation course, PGK12.1 cells were fixed in $2 \%$ formaldehyde for 15 min prior to permeabilization. The antibodies used were $\alpha-\mathrm{H} 3 \mathrm{~K} 27 \mathrm{me} 3 \mathrm{mAb}$ (Abcam, ab6002; Active Motif, ab61017), $\alpha$-CIZ1 N-terminal (1794), $\alpha$-CIZ1 C-terminal (Novus, NB100-74624), SAFA anti-HNRNP-U (Abcam, ab10297), and anti-YY1 (SC7341). Coverslips were costained with limiting concentrations of Hoechst 33258 (10 ng/mL; Sigma) for quantitative detection of chromatin.

\section{RNA-FISH}

Female cultured cells were processed for the detection of Xist transcript (red) by RNA-FISH followed by immuno-FISH for CIZ1 (green) using N-terminal antibody 1794. An 11-kb Spe1-Sall mouse Xist fragment was fluorescently tagged with Cy3-dUTP (GE Healthcare) using BioPrime labeling kit (Invitrogen). Samples were incubated with probe overnight at $37^{\circ} \mathrm{C}$. For subsequent detection of CIZ1, antibody 1794 was applied for $1 \mathrm{~h}$ followed by secondary anti-rabbit FITC (Sigma) for $1 \mathrm{~h}$. Cells were imaged and processed using Adobe Photoshop CS4 to enhance signal definition. Prior RNA-FISH processing resulted in reduced CIZ1 signal intensity throughout the nucleus. For SR 3D-SIM and RNA-FISH on splenocyte Xist, cDNA was labeled with Spectrum greendUTP or Spectrum red-dUTP by nick translation (Abbott Molecular). Following fixation and permeabilization, cells were incubated with primary antibody for $1 \mathrm{~h}$ and then with Alexa fluor goat antirabbit 594 for $30 \mathrm{~min}$ and then washed and post-fixed before detection of Xist overnight. After extensive washing, the cells were incubated with $2 \mu \mathrm{g} / \mathrm{mL}$ DAPI and mounted with VectorShield.

Chromosome paints

FITC-conjugated X-chromosome paint (AMP OXG) was used as instructed (Cytocell Ltd.). Labeled cells were mounted in VectorShield with DAPI and imaged.

\section{Microscopy}

Images were collected using a Zeiss Axiovert 200M and Axiocam and Openlab image acquisition software and quantified using ImageJ (National Institutes of Health) using raw images acquired under identical conditions. Images for publication were enhanced using Adobe Photoshop or Affinity Photo 1.4 by applying identical manipulations to test and control samples so that image intensities reflect actual relationships. Live images were collected on a PE Ultraview spinning-disk confocal microscope. SR 3DSIM was performed on a DeltaVision OMX V3 Blaze system (GE Healthcare) equipped with a $60 \times / 1.42$ NA plan apo oil immersion objective (Olympus), sCMOS cameras (PCO), and 405-,
488-, and 593-nm lasers. 3D-SIM image stacks were acquired as described in the Supplemental Material.

\section{Acknowledgments}

X-chromosome paints were a kind gift from Cytocell. We are grateful to James Hewitson, Dimitris Lagos, Mike Shires, and Matthew Wiseman for advice or assistance, and Sally James, Richard Randle-Boggis, Katherine Newling, and Peter Ashton of York Technology Facility Genomics laboratory. This work was supported by a Radhika Sreedhar Scholarship to R.R.-F., University of York priming funds, Biotechnology and Biological Sciences Research Council PhD training scholarships to E.R.S. and R.W., Genetics Society training funds to R.R., Wellcome Trust grants to N.B. $(081385,091911)$, and the Micron Advance Imaging Initiative (Wellcome Trust 103768).

\section{References}

Ainscough JF, Rahman FA, Sercombe H, Sedo A, Gerlach B, Coverley D. 2007. C-terminal domains deliver the DNA replication factor Ciz1 to the nuclear matrix. J Cell Sci 120: 115-124.

Bardelli M, Leucci E, Schurfeld K, Bellan C, Passiatore G, Rocchigiani M, Bartolommei S, Orlandini M, Zagursky J, Lazzi S, et al. 2007. VEGF-D is expressed in activated lymphoid cells and in tumors of hematopoietic and lymphoid tissues. Leuk Lymphoma 48: 2014-2021.

Bianchi I, Lleo A, Gershwin ME, Invernizzi P. 2012. The X chromosome and immune associated genes. I Autoimmun 38: J187-J192.

Brockdorff N, Ashworth A, Kay GF, McCabe VM, Norris DP, Cooper PJ, Swift S, Rastan S. 1992. The product of the mouse Xist gene is a $15 \mathrm{~kb}$ inactive $\mathrm{X}$-specific transcript containing no conserved ORF and located in the nucleus. Cell 71: $515-526$.

Brown CJ, Willard HF. 1994. The human X-inactivation centre is not required for maintenance of $\mathrm{X}$-chromosome inactivation. Nature 368: 154-156.

Brown CJ, Hendrich BD, Rupert JL, Lafreniere RG, Xing Y, Lawrence J, Willard HF. 1992. The human XIST gene: analysis of a $17 \mathrm{~kb}$ inactive X-specific RNA that contains conserved repeats and is highly localized within the nucleus. Cell 71: 527-542.

Caparros ML, Alexiou M, Webster Z, Brockdorff N. 2002. Functional analysis of the highly conserved exon IV of XIST RNA. Cytogenet Genome Res 99: 99-105.

Charfi C, Edouard E, Rassart E. 2014. Identification of GPM6A and GPM6B as potential new human lymphoid leukemia-associated oncogenes. Cell Oncol (Dordr) 37: 179-191.

Chen CK, Blanco M, Jackson C, Aznauryan E, Ollikainen N, Surka C, Chow A, Cerase A, McDonel P, Guttman M. 2016. Xist recruits the $\mathrm{X}$ chromosome to the nuclear lamina to enable chromosome-wide silencing. Science 354: 468-472.

Chu C, Zhang QC, da Rocha ST, Flynn RA, Bharadwaj M, Calabrese JM, Magnuson T, Heard E, Chang HY. 2015. Systematic discovery of Xist RNA binding proteins. Cell 161: 404-416.

Clemson CM, McNeil JA, Willard HF, Lawrence JB. 1996. XIST RNA paints the inactive $\mathrm{X}$ chromosome at interphase: evidence for a novel RNA involved in nuclear/chromosome structure. J Cell Biol 132: 259-275.

Copeland NA, Sercombe HE, Ainscough JF, Coverley D. 2010. Cizl cooperates with cyclin-A-CDK2 to activate mammalian DNA replication in vitro. J Cell Sci 123: 1108-1115. 
Copeland NA, Sercombe HE, Wilson RH, Coverley D. 2015. Cyclin-A-CDK2-mediated phosphorylation of CIZ1 blocks replisome formation and initiation of mammalian DNA replication. J Cell Sci 128: 1518-1527.

Coverley D, Marr J, Ainscough J. 2005. Ciz1 promotes mammalian DNA replication. J Cell Sci 118: 101-112.

Csankovszki G, Panning B, Bates B, Pehrson JR, Jaenisch R. 1999. Conditional deletion of Xist disrupts histone macroH2A localization but not maintenance of $\mathrm{X}$ inactivation. Nat Genet 22: 323-324.

da Rocha ST, Boeva V, Escamilla-Del-Arenal M, Ancelin K, Granier C, Matias NR, Sanulli S, Chow J, Schulz E, Picard C, et al. 2014. Jarid2 is implicated in the initial Xist-induced targeting of PRC2 to the inactive X chromosome. Mol Cell 53: 301-316.

den Hollander P, Rayala SK, Coverley D, Kumar R. 2006. Ciz1, a novel DNA-binding coactivator of the estrogen receptor $a$, confers hypersensitivity to estrogen action. Cancer Res 66: 11021-11030.

Duthie SM, Nesterova TB, Formstone EJ, Keohane AM, Turner BM, Zakian SM, Brockdorff N. 1999. Xist RNA exhibits a banded localization on the inactive $\mathrm{X}$ chromosome and is excluded from autosomal material in cis. Hum Mol Genet 8: 195-204.

Engreitz JM, Pandya-Jones A, McDonel P, Shishkin A, Sirokman K, Surka C, Kadri S, Xing J, Goren A, Lander ES, et al. 2013. The Xist lncRNA exploits three-dimensional genome architecture to spread across the $\mathrm{X}$ chromosome. Science 341: 1237973.

Greaves EA, Copeland NA, Coverley D, Ainscough JF. 2012. Cancer-associated variant expression and interaction of CIZ1 with cyclin A1 in differentiating male germ cells. J Cell Sci 125: 2466-2477.

Guo B, Odgren PR, van Wijnen AJ, Last TJ, Nickerson J, Penman S, Lian JB, Stein JL, Stein GS. 1995. The nuclear matrix protein NMP-1 is the transcription factor YY1. Proc Natl Acad Sci 92: 10526-10530.

Hall LL, Byron M, Pageau G, Lawrence JB. 2009. AURKB-mediated effects on chromatin regulate binding versus release of XIST RNA to the inactive chromosome. I Cell Biol 186: 491-507.

Hasegawa Y, Brockdorff N, Kawano S, Tsutui K, Tsutui K, Nakagawa S. 2010. The matrix protein hnRNP $U$ is required for chromosomal localization of Xist RNA. Dev Cell 19: 469-476.

Heard E, Disteche CM. 2006. Dosage compensation in mammals: fine-tuning the expression of the $\mathrm{X}$ chromosome. Genes Dev 20: $1848-1867$.

Helbig R, Fackelmayer FO. 2003. Scaffold attachment factor A (SAF-A) is concentrated in inactive $\mathrm{X}$ chromosome territories through its RGG domain. Chromosoma 112: 173-182.

Higgins G, Roper KM, Watson IJ, Blackhall FH, Rom WN, Pass HI, Ainscough JF, Coverley D. 2012. Variant Cizl is a circulating biomarker for early-stage lung cancer. Proc Natl Acad Sci 109: E3128-E3135.

Jeon Y, Lee JT. 2011. YY1 tethers Xist RNA to the inactive X nucleation center. Cell 146: 119-133.

Kolpa HJ, Fackelmayer FO, Lawrence JB. 2016. SAF-A requirement in anchoring XIST RNA to chromatin varies in transformed and primary cells. Dev Cell 39: 9-10.

Lee JT, Bartolomei MS. 2013. X-inactivation, imprinting, and long noncoding RNAs in health and disease. Cell 152: 1308-1323.

Lee JT, Strauss WM, Dausman JA, Jaenisch R. 1996. A 450 kb transgene displays properties of the mammalian X-inactivation center. Cell 86: 83-94.
Leong HS, Chen K, Hu Y, Lee S, Corbin J, Pakusch M, Murphy JM, Majewski IJ, Smyth GK, Alexander WS, et al. 2013. Epigenetic regulator Smchd1 functions as a tumor suppressor. Cancer Res 73: 1591-1599.

Makhlouf M, Ouimette JF, Oldfield A, Navarro P, Neuillet D, Rougeulle C. 2014. A prominent and conserved role for YY1 in Xist transcriptional activation. Nat Commun 5: 4878.

McHugh CA, Chen CK, Chow A, Surka CF, Tran C, McDonel P, Pandya-Jones A, Blanco M, Burghard C, Moradian A, et al. 2015. The Xist lncRNA interacts directly with SHARP to silence transcription through HDAC3. Nature 521: 232-236.

Mitsui K, Matsumoto A, Ohtsuka S, Ohtsubo M, Yoshimura A. 1999. Cloning and characterization of a novel p21/Cip1/ Waf1)-interacting zinc finger protein, ciz1. Biochem Biophys Res Commun 264: 457-464.

Moindrot B, Cerase A, Coker H, Masui O, Grijzenhout A, Pintacuda G, Schermelleh L, Nesterova TB, Brockdorff N. 2015. A pooled shRNA screen identifies Rbm15, Spen, and Wtap as factors required for Xist RNA-mediated silencing. Cell Rep 12: $562-572$.

Monfort A, Di Minin G, Postlmayr A, Freimann R, Arieti F, Thore S, Wutz A. 2015. Identification of Spen as a crucial factor for Xist function through forward genetic screening in haploid embryonic stem cells. Cell Rep 12: 554-561.

Nesterova TB, Slobodyanyuk SY, Elisaphenko EA, Shevchenko AI, Johnston C, Pavlova ME, Rogozin IB, Kolesnikov NN, Brockdorff N, Zakian SM. 2001. Characterization of the genomic Xist locus in rodents reveals conservation of overall gene structure and tandem repeats but rapid evolution of unique sequence. Genome Res 11: 833-849.

Nishibe R, Watanabe W, Ueda T, Yamasaki N, Koller R, Wolff L, Honda Z, Ohtsubo M, Honda H. 2013. CIZ1, a p21Cip1/Waf1interacting protein, functions as a tumor suppressor in vivo. FEBS Lett 587: 1529-1535.

Pazgal I, Boycov O, Shpilberg O, Okon E, Bairey O. 2007. Expression of VEGF-C, VEGF-D and their receptor VEGFR-3 in diffuse large B-cell lymphomas. Leuk Lymphoma 48: 2213-2220.

Penny GD, Kay GF, Sheardown SA, Rastan S, Brockdorff N. 1996. Requirement for Xist in $\mathrm{X}$ chromosome inactivation. Nature 379: 131-137.

Pollex T, Heard E. 2012. Recent advances in X-chromosome inactivation research. Curr Opin Cell Biol 24: 825-832.

Rahman FA, Aziz N, Coverley D. 2010. Differential detection of alternatively spliced variants of Cizl in normal and cancer cells using a custom exon-junction microarray. BMC Cancer 10: 482 .

Sakaguchi T, Hasegawa Y, Brockdorff N, Tsutsui K, Tsutsui KM, Sado T, Nakagawa S. 2016. Control of chromosomal localization of Xist by hnRNP U family molecules. Dev Cell 39: $11-12$.

Savarese F, Flahndorfer K, Jaenisch R, Busslinger M, Wutz A. 2006. Hematopoietic precursor cells transiently reestablish permissiveness for X inactivation. Mol Cell Biol 26: 71677177.

Sheardown SA, Duthie SM, Johnston CM, Newall AE, Formstone EJ, Arkell RM, Nesterova TB, Alghisi GC, Rastan S, Brockdorff N. 1997. Stabilization of Xist RNA mediates initiation of X chromosome inactivation. Cell 91: 99-107.

Simon MD, Pinter SF, Fang R, Sarma K, Rutenberg-Schoenberg M, Bowman SK, Kesner BA, Maier VK, Kingston RE, Lee JT. 2013. High-resolution Xist binding maps reveal two-step spreading during X-chromosome inactivation. Nature 504: 465-469.

Smeets D, Markaki Y, Schmid VI, Kraus F, Tattermusch A, Cerase A, Sterr M, Fiedler S, Demmerle J, Popken J, et al. 
2014. Three-dimensional super-resolution microscopy of the inactive X chromosome territory reveals a collapse of its active nuclear compartment harboring distinct Xist RNA foci. Epigenetics Chromatin 7: 8.

Spatz A, Borg C, Feunteun J. 2004. X-chromosome genetics and human cancer. Nat Rev Cancer 4: 617-629.

Wang J, Syrett CM, Kramer MC, Basu A, Atchison ML, Anguera MC. 2016. Unusual maintenance of $\mathrm{X}$ chromosome inactivation predisposes female lymphocytes for increased expression from the inactive X. Proc Natl Acad Sci 113: E2029-E2038.

Ward JM. 2006. Lymphomas and leukemias in mice. Exp Toxicol Pathol 57: 377-381.

Wilson RH, Coverley D. 2013. Relationship between DNA replication and the nuclear matrix. Genes Cells 18: 17-31.

Wilson RH, Hesketh EL, Coverley D. 2016. Preparation of the nuclear matrix for parallel microscopy and biochemical analyses. Cold Spring Harb Protoc doi: 10.1101/pdb.prot083758.
Wutz A, Jaenisch R. 2000. A shift from reversible to irreversible X inactivation is triggered during ES cell differentiation. Mol Cell 5: 695-705.

Wutz A, Rasmussen TP, Jaenisch R. 2002. Chromosomal silencing and localization are mediated by different domains of Xist RNA. Nat Genet 30: 167-174.

Xiao J, Vemula SR, Xue Y, Khan MM, Kuruvilla KP, MarquezLona EM, Cobb MR, LeDoux MS. 2016. Motor phenotypes and molecular networks associated with germline deficiency of Ciz1. Exp Neurol 283: 110-120.

Yamada N, Hasegawa Y, Yue M, Hamada T, Nakagawa S, Ogawa Y. 2015. Xist exon 7 contributes to the stable localization of Xist RNA on the inactive X-chromosome. PLoS Genet 11: e1005430.

Yildirim E, Kirby JE, Brown DE, Mercier FE, Sadreyev RI, Scadden DT, Lee JT. 2013. Xist RNA is a potent suppressor of hematologic cancer in mice. Cell 152: 727-742. 


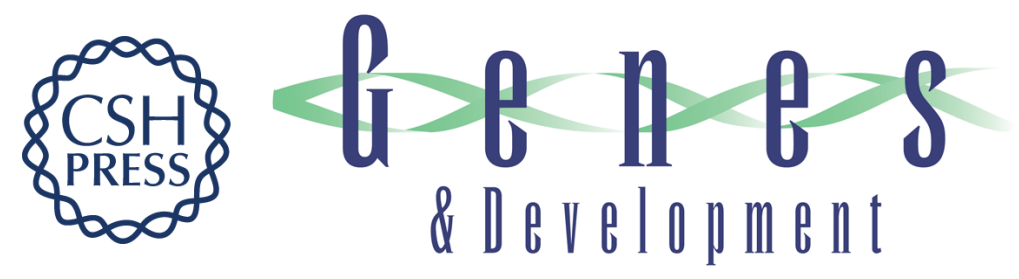

\title{
The nuclear matrix protein $\mathrm{ClZ1}$ facilitates localization of Xist RNA to the inactive $\mathrm{X}$-chromosome territory
}

\author{
Rebeca Ridings-Figueroa, Emma R. Stewart, Tatyana B. Nesterova, et al.
}

Genes Dev. 2017, 31: originally published online May 25, 2017

Access the most recent version at doi:10.1101/gad.295907.117

\section{Supplemental http://genesdev.cshlp.org/content/suppl/2017/05/25/gad.295907.117.DC1 Material}

References This article cites 57 articles, 18 of which can be accessed free at: http://genesdev.cshlp.org/content/31/9/876.full.html\#ref-list-1

Creative This article, published in Genes \& Development, is available under a Creative Commons Commons License (Attribution-NonCommercial 4.0 International), as described at License http://creativecommons.org/licenses/by-nc/4.0/.

Email Alerting Receive free email alerts when new articles cite this article - sign up in the box at the top Service right corner of the article or click here.

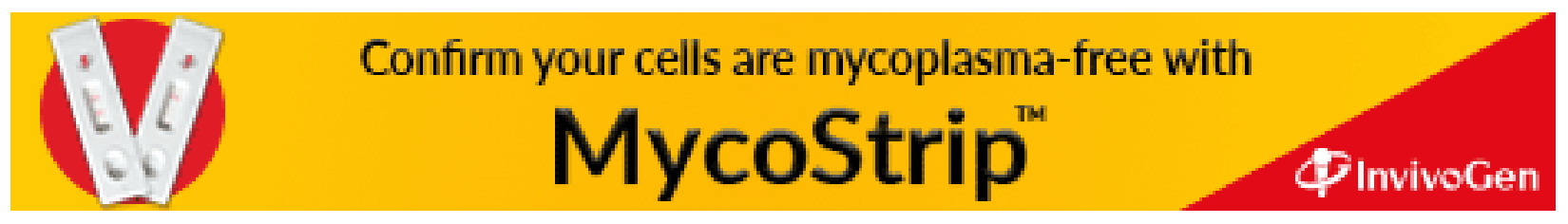

